\title{
Structural development and regional concentration of agriculture in Finland in 1975-2008
}

\author{
Olli Voutilainen ${ }^{1}$, Toivo Muilu ${ }^{2,3,4}$, Olli Wuori ${ }^{2}$ \\ ${ }^{1}$ Tempo Economics Itd., Teknobulevardi 3-5, Fl-01530 Vantaa, Finland \\ ${ }^{2}$ MTT Agrifood Research Finland, Economic Research, Latokartanonkaari 9, Fl-00790 Helsinki, Finland \\ ${ }^{3}$ Department of Geography, PO Box 3000 (Linnanmaa campus), FI-90014 University of Oulu, Finland \\ ${ }^{4}$ Thule Institute, PO Box 73000 (Linnanmaa campus), FI-90014 University of Oulu, Finland \\ e-mail: toivo.muilu@mtt.fi
}

\begin{abstract}
This article analyses structural and regional development and concentration of agriculture in terms of jobs and value of production, here value added, in Finland during 1975-2008 based on statistical and georeferenced data. The empirical results showed us that, while the relative socioeconomic importance of agriculture has decreased all over Finland, the role of agriculture varies a great deal between regions. Agricultural development trends both in terms of number of jobs and value of production, have been different from total economic development since the mid-1980s. As with economic functions in general, a regional concentration trend has taken place in agriculture. However, this trend has been stronger in all industries together and compared to other industries, agriculture as a whole is still regionally evenly dispersed. The reasons behind this can be found in historical, societal and political factors, and tight connections between agriculture and surrounding land and natural circumstances.
\end{abstract}

Key words: regional concentration, structural change, agriculture, Finland, Gini coefficient

\section{Introduction}

The role of agriculture as a basic industry in rural areas has been diminishing in Western Countries during last decades. On the other hand, phenomena like population growth, urbanisation, global warming, production of renewable energy and food crises have brought along with them new and often conflicting viewpoints to the discussion on the status of agriculture. Food production along with clean freshwater are, of course, ultimate prerequisites for human action and they govern the socioeconomic development and position of societies and communities from the global to the local level.

This study analyses structural and regional development and concentration of agriculture in Finland during 19752008 based on statistical and georeferenced data. Finland is an interesting case study area, since it is the northernmost country in the world where an extensive rural population and early economic development of the society have been centrally based on primary industries (Alalammi 1982). On the other hand, extreme climate conditions caused by its northern location, long internal distances and relatively small volume of production have increased agriculture's sensitivity to changes. This has resulted in structural changes to agriculture in western societies, in many cases, being more severe in Finland compared to continental countries of Europe.

The article begins with a short review on the evolution of agriculture in Finland in order to gain a general view of the changes, which enables us to logically situate the recent development into the proper historical context. Next, some relevant theoretical approaches and previous studies will be reviewed, dealing especially with regional terms explaining development and specialisation of agriculture. In the empirical part, data and methods employed will first be introduced before the empirical analysis, results and interpretations, and finally some concluding remarks are made. 


\section{Evolution of agriculture in Finland}

As in all countries, the early stages of agriculture in Finland were connected to the settlement of the country (Katajamäki 1988, Junttila 1991, Huurre 2003). For centuries agricultural production was regionally fairly concentrated, since food was produced, processed and consumed in or near farmsteads. Most of the people lived in the vicinity of coastal regions, because food production and processing were also concentrated in coastal areas but not evenly, however (Yrjölä 2010).

Regional specialisation of Finnish agriculture began already in the Middle Ages (Orrman 2003). In the $19^{\text {th }}$ century there were roughly three great farming areas in the country: the field cultivation area of Western Finland, the slash and burn agricultural area of Eastern Finland and the animal husbandry area of Northern Finland (Soininen 1974). Katajamäki (1988) summed up that the still evident east-west division in the spatial division of labour in agriculture was visible already in the beginning of the $19^{\text {th }}$ century.

During the latter part of $19^{\text {th }}$ century began a transition period from traditional to modern agriculture, which was connected to changing relations between primary and secondary production. Market prices of grain products fell in the world markets, which favoured animal husbandry. At the same time the woodworking industry expanded in Finland and increased the value of forests. In the early $20^{\text {th }}$ century both agricultural production and food processing began to concentrate in the most favourable areas. Resultant phenomena were a decrease in the number of farms and work force in agriculture, mechanisation and intensification of production, regional and farm-specific specialisation and diminution of farm-level self-sufficiency (Yrjölä 2010).

The so called "Tenant Law" (Torpparilaki in Finnish) in 1918 meant remarkable emancipation in land ownership in rural areas (Granberg 1989, Peltonen 2004). However, there were still a lot of people without their own farmland and new resettlement laws were passed in 1922 and 1936 (Varjo 1977b, Varjo 1980). The Great Depression of the 1930s shook structures of Finnish farming, but the number of jobs in agriculture increased even until 1940, although the number of industrial jobs already grew more rapidly (Rantatupa 2004). The share of primary jobs in relation to all jobs was about $60 \%$ in 1940, whilst the share of industrial jobs was $14 \%$ (Katajamäki 1988). The combination of seasonal logging and dairy husbandry in farms started to spread from western areas and was a basic type of small farm especially in Eastern and Northern Finland until the 1970s (Granberg 1989, Östman 2004).

After WWII a broad cession of territory to the Soviet Union challenged resettlement legislation and policy when about 40000 farm families had to be resettled, among other refugees. The Land Acquisition Law (Maanhankintalaki in Finnish) was passed in 1945 and enabled giving these families, as well as the demobilised soldiers, their own land mostly from state-owned areas. Especially in Eastern and Northern Finland those areas were in many cases forests and boglands where no agriculture had been practiced earlier, and these new farms were later called "cold farms". One hidden aim behind this resettlement policy was to confirm peace and avoid dissatisfaction within the society. Partly due to this resettlement a language policy was also included, since the Finnish-speaking immigrants were very seldom placed in Swedish-speaking areas (Varjo 1977a, Varjo 1980, Roiko-Jokela 2004).

At the same time agriculture itself met major changes, especially due to scientific progress. Intensification of crop husbandry was rapid due to the developments in artificial fertilisation, pesticides, plant breeding, cultivation techniques and mechanisation. Animal production also became more effective along with progression of feeding, cowhouse construction and animal breeding (Jussila 1987, Katajamäki 1988, Junttila 1991, Niemelä 2004). The critical period of Finnish agriculture was in the 1960s and 1970s, which was much later than in most western countries. New technologies replaced human labour in farms, first among wageworkers, then assisting family members and finally also among farmers in the late 1960s (Granberg 1989, Muilu 1990).

The drastic decrease in farms following WWII is an excellent indicator of the major structural changes in agriculture during that time period. The highest number of farms was when there were more than 300000 farms in the early 1960s when the resettlement policy ended. Till the early 1990s the number of active farms had decreased to 120000 (Pyykkönen 2001). At the time of Finland's entry into the EU in 1995 the number was about 100000 , and in 2010 only 63000 (Niemi \& Ahlstedt 2011). Hence, the structural change of agriculture has clearly continued during EU membership. 
In conclusion, the evolution of Finnish agriculture to its present form has been controlled by a mixture of natural, societal and political premises. In general, agricultural production self-evidently tends to concentrate in areas where local conditions are most favourable, i.e., in southern and western Finland (see more about natural conditions for practicing agriculture in Finland: Finnish Meteorological Institute a, Finnish Meteorological Institute b, Varjo 1977a, Varjo 1980, Rosenqvist 1997, Ministry of Agriculture and Forestry 2002). Respectively, also the other economic activities and population are concentrated in the same areas because the circumstances for other economic activities are notably better in urban-adjacent rural areas - which in turn are mainly situated in southern and western parts of Finland - compared to other rural areas (see e.g. Malinen et al. 2006). This means that the comparative advantage of practicing economic activities other than agriculture can often be the largest in urban-adjacent rural areas, which in turn can marginalise agriculture in these areas. Although the conditions for practicing agriculture would have been better than in other areas, the comparative advantage of practicing other economic activity can be higher (see more about regional comparative advantage in general: Armstrong \& Taylor 2000). In addition, agricultural subsidies are lower and less secure in southern Finland than in the more northern areas, which in turn can affect the decreasing role of agriculture (Breman et al. 2010).

\section{Approaches to regional concentration of agriculture}

Traditionally, the numerous factors explaining the specialisation and differentiation of agriculture have been noted. Grigg (1995) classifies these factors as

1. the factors related to the physical environment and natural growth conditions

2. the economic geographical models explaining the location of agriculture, of which the model of J. H. von Thunen is the most influential one

3. behavioural approaches, i.e., the studies that explain agricultural variations in terms of individual, farmers' behaviours

4. internationalisation and modernisation of agriculture and the political economy approach.

In the Finnish context, Junttila (1991), for instance, divides the factors affecting spatial division of agricultural labour into natural circumstances, historical and economical factors and the factors relating to agricultural policy. In this article, the particular interest is in the regional dimension in the structural change of agriculture.

Regional specialisation and concentration of Finnish agriculture has been analysed especially under the discipline of agricultural geography. However, during the past decades, the subject has not been studied considerably. All in all, for many decades regional specialisation of Finnish agriculture has been identified (Varjo 1956, Smeds 1963a, 1963b, Alestalo 1965, Fogelberg 1965, Talman 1980, 1981, Häkkilä 1984, Niemi \& Häkkilä 1988, Junttila 1991, Katajamäki 1991, Rosenqvist 1997, Tiainen and Juntunen 2006). In general, according to agricultural geographers, commercialisation of agriculture and natural circumstances, in particular, have been the key reasons behind the regional diversification of agriculture in Finland (Rosenqvist 1997). Rosenqvist (1997) himself emphasises the average unit sizes of the farms in the regions (characterising fordistic structural change) and the opportunities and the limitations for practicing agriculture brought about by natural circumstances as the main factors explaining regional specialisation of agriculture. Furthermore, according to Rosenqvist (ibid.), the regionally differentiated agricultural support affects the specialisation of agriculture. In more general terms, agricultural income and farm management decisions are highly dependent on the design and scope of policy measures (see more about the territorial impact of agricultural and rural development policy at the EU level: Shucksmith et al. 2005, and in Finland: Voutilainen 2012). All in all, within agriculture, a regional diversification and different development trends have taken place, which can, at least partly, be explained by many factors such as natural and environmental conditions, but also by historical and cultural factors, and economic and societal factors (Rosenqvist 1997).

In general in regional studies, the regional differentiation or diversification of economic activities is explained by the concept of the spatial division of labour (see e.g. Massey 1984), which has been one of the most important factors explaining the polarisation and diversification of regions and rural areas in Finland and other countries as well (see more about the settlement and formation of spatial division of labour in Finland: Katajamäki 1988, Tykkyläinen and Kavilo 1991). The diversification of regional economic activities and functions can be divided into three factors. Firstly, the differences between the natural conditions and circumstances usually create rather con- 
stant, zonal structures. An example of this is the Finnish settlement structure which extends to nearly all parts of Finland and is the result of practicing agriculture and forestry. Secondly, the settlement centres create strengthening, zonal core-periphery -structures. Thirdly, the regional diversification is affected by a number of local factors, which, in turn, create complex and mosaic-type regional structures (Malinen and Muilu 2009).

Regional specialisation means that enterprises and functions are concentrated in a certain region. These functions directly benefit from each other but the functions focus on a narrow area. The latter fact also means that the functions of an enterprise do not necessarily benefit the other enterprises functioning in the same area (Huovari et al. 2001). According to Rosenqvist (1997), the concept of specialisation is closely related to the concept of division of labour, and in economics, the division of labour and specialisation have been emphasised as a crucial source of economic growth. Granberg (1989) argues that the farms - when specialising and orienting themselves more towards markets - begin to compete with each other more than earlier, even though the farms were situated far from each other. Thus, regional division of labour is one dimension of specialisation (ibid.). The regional division in agriculture means that the regions have specialised in certain production line or lines, and hence the regional concentrations of certain production lines can be composed.

According to the so called New Regional Geography, (see e.g. Krugman 1991, Venables 1996, Krugman 1998, Fujita et al. 1999, Krugman 2011), specialisation and concentration of regional economies are continuously more emphasised as the precondition of the development of regions and the accelerator of regional economic growth. According to this paradigm, economic life is concentrating (in the case of Finland, see: Tohmo and Littunen 2002, Tohmo 2007). Concentration and specialisation processes have been indicated to promote the well-being of populations and competitiveness, although the impacts of these processes are not the same between separate regions, of course. In general and in theoretical terms, specialisation is based on the so called cumulative causality process originating from the idea of Myrdal (1957). According to this idea, the benefits of the economies of scale make the business activity of the enterprises more profitable. The existing group of enterprises attracts more enterprises and labour force to the same region. In this way the concentration of development of economic activities is reinforced (Tohmo 2007).

Agriculture was a dominant sector of Finnish society for a long time. After the dominance of agriculture, the strong process of industrialisation and later the transition towards the dominance of the service sector have taken place. However, on the regional level, the picture is not that simple or homogenous. From a historical point of view in Finland, the more profitable production line has pushed the earlier main production line further away from coastal areas (see e.g. Ajo 1947, Katajamäki 1988). Making general theoretical statements is difficult because we do not live in a homogenous area. Conversely, the circumstances or conditions for socioeconomic activities differ regionally. In certain regions, the natural circumstances and distance factors (including accessibility) have made favourable regional development possible, while - because of the same factors - the development has been negative in some other regions. Regions are said to have so called "first nature" describing the region's resources prior to the arrival of humans and human activity. However, "first nature" alone cannot explain dramatic differences in regional economic development. Functioning of human being leads to so called "second nature" of a region and hence differentiation in the circumstances of a region and uneven development even across ex ante identical places (Ottaviano and Pinelli 2004). Furthermore, coincidence can play a crucial role when explaining the original situation patterns and later concentration development between different activities.

\section{Material and methods}

\section{Material}

The empirical material of the article is based on the Regional Account statistics provided by Statistics Finland (see Statistics Finland). In the database, LAU-1 level (so called subregions in Finland) data can be utilised when analysing the regional development and concentration of different industries in terms of jobs and value added, for instance. LAU-1 level can be argued to be a suitable regional level in the analysis because then the number of observations in each region is sufficient and the data divided into the regional entities in question is still manageable. The time period available in the database is from 1975 to 2008. The statistical data used in the article are based on the municipal and regional divisions in force in 2008. 


\section{Methods}

The indicators used in the analysis of regional concentration of agriculture are the number of jobs and value added in agriculture. Here, the jobs in a certain region include all the jobs in a given region irrespective of whether the job is done by a person living in the same subregion or in another subregion. Every employed person aged 15-74 years old, both employee and entrepreneur - also part-time workers - constitutes one job (see more: Statistics Finland).

Value added can be defined as the difference between the total sales revenue of an industry and the total cost of components, materials, and services purchased from other firms within a given reporting period (usually one year). This is the industry's contribution to the gross domestic product (GDP). Value added does not include the production subsidies of agriculture.

In this article, the Gini index (or coefficient) is the main tool used when analysing the regional concentration of agriculture and economic activities as a whole and is a measure of statistical dispersion. The Gini index is based on the Lorenz curve, which, in turn, graphically shows the degree of inequality that exists in the distributions of two variables. The Gini index can be defined as a summary numerical measure of how unequally one variable is related to another. The Gini index represents twice the area between the Lorenz function and the diagonal plotted in the unit square. Here, the value of Gini coefficient tells us how regionally concentrated or dispersed the activities are compared to perfectly concentrated or perfectly dispersed distributions. The minimum value of the Gini index is 0 and the maximum value is 1 . When the value is 1 the activity is perfectly (here: regionally) concentrated and when the value is 0 the activity is perfectly (here: regionally) dispersed. The Gini index is calculated here as follows ${ }^{1}$ :

$$
\text { Gini coefficient }=1-_{-}^{1}{ }_{s} \sum_{i=1}^{s-1} l_{i}
$$

where

$s=$ number of subintervals

$\mathrm{i}=$ subscript for breakpoint

$I_{i}=$ is the $i^{\text {th }}$ Lorenz function break point

Furthermore, a few cartographic presentations are utilised because these are demonstrative when analysing regional variations between numerous regional entities.

\section{Results}

\section{Change in number jobs and value added in agriculture at country level}

As a result of the change in economic structure, the role of agriculture has decreased in terms of number of jobs and in terms of the share of value added in total production. During 1975-2008, both the total number of jobs and total value added in all industries together has increased. The number of jobs in agriculture has decreased by 198000 jobs while the total number of jobs has increased by 202000 . Hence, the share of jobs in agriculture has notably decreased, being $4 \%$ in 2008. As with the development in agricultural jobs, the share of agriculture in total value added has notably decreased, being slightly below $1 \%$ in 2008 (Table 1). Value added does not contain the production subsidies of agriculture. The production support for agricultural and horticultural production totalled $€ 2$. 2 billion in 2008 (Niemi and Ahlstedt 2010). The lower share of value added in agriculture compared to the share of agriculture in total jobs indicates that agriculture is an industry that is not as productive as other industries on average.

Table 1. Development of agriculture in Finland in 1975-2008 (Statistics Finland).

\begin{tabular}{lllllc}
\hline & \multicolumn{2}{l}{ Number of jobs } & & \multicolumn{3}{c}{ Value added, mill. $€$, nominal values } \\
& 1975 & 2008 & Change $\%$ & 1975 & 2008 \\
\hline All industries & 2323100 & 2525300 & 8.7 & 16356.4 & 161503.7 \\
Agriculture & 296500 & 98500 & -66.8 & 946.1 & 1327 \\
Share of agriculture \% & 12.8 & 3.9 & & 5.8 & 40.3 \\
\hline
\end{tabular}

\footnotetext{
${ }^{1}$ The statistical program WinIDAMS by the UNESCO is used for the calculations of the Gini indices (for further information: see UNESCO).
} 
Compared to annual development of total value added, the equivalent development of value added in agriculture has varied more. This is due to annual changes in the weather conditions, but also due to changes in the product and input prices of agriculture. When examining all the industries together, the annual change in value added has been continuously positive during 1975-2008 except during the economic depression in the early 1990s. The development trends of total value added and value added in agriculture seem to have separated from each other since the mid-1980s, as is also the case when comparing total employment and agricultural jobs. The number of jobs in agriculture has continuously decreased during 1975-2008 but the decrease has been slower in the 2000s. This indicates that it is no longer possible to increase productivity of agriculture as fast as in previous decades. When examining total employment, there was a notable decrease in the number of jobs during the recession of the 1990s. After that, the number of jobs has continuously increased. All in all, agricultural development trends both in terms of jobs and value added has been clearly different from total economic development since the mid-1980s (Fig. 1).

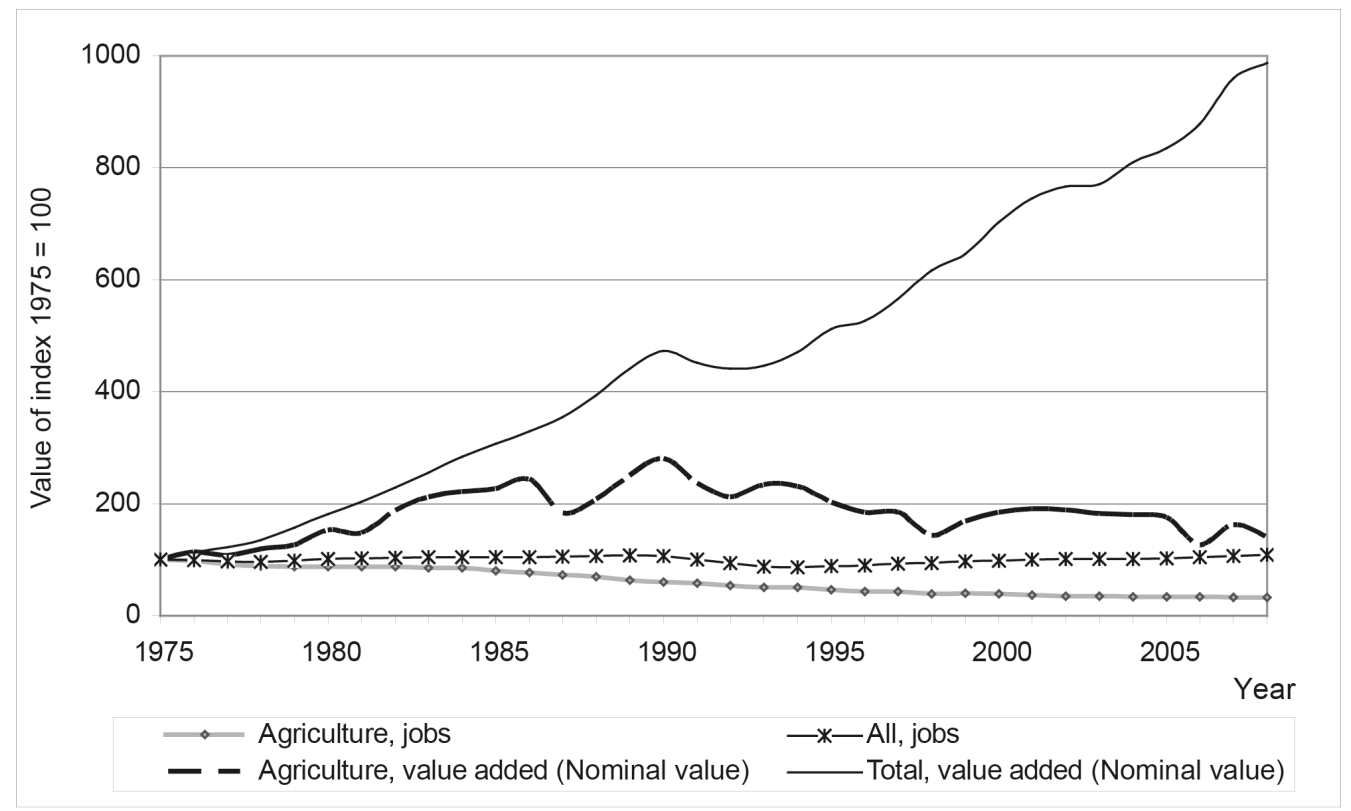

Fig. 1. Change in number of jobs and value added (at nominal prices) in 1975-2008 (Source of the raw data: Statistics Finland).

\section{Change in regional level}

Socioeconomic significance of agriculture varies notably between the subregions of Finland (Fig. 2 and Fig. 3). In the light of value of production (i.e. value added), the relative role of agriculture has become quite marginal in a majority of the subregions. From the viewpoint of employment, instead, the relative role of agriculture is still quite notable in many regions. The socioeconomic role of agriculture seems to be more notable than average especially in many subregions of the western and central part Finland, but also in certain subregions of eastern and northern Finland. All in all, the role of agriculture both in terms of jobs and value added has notably decreased all over the country during 1975-2008. 

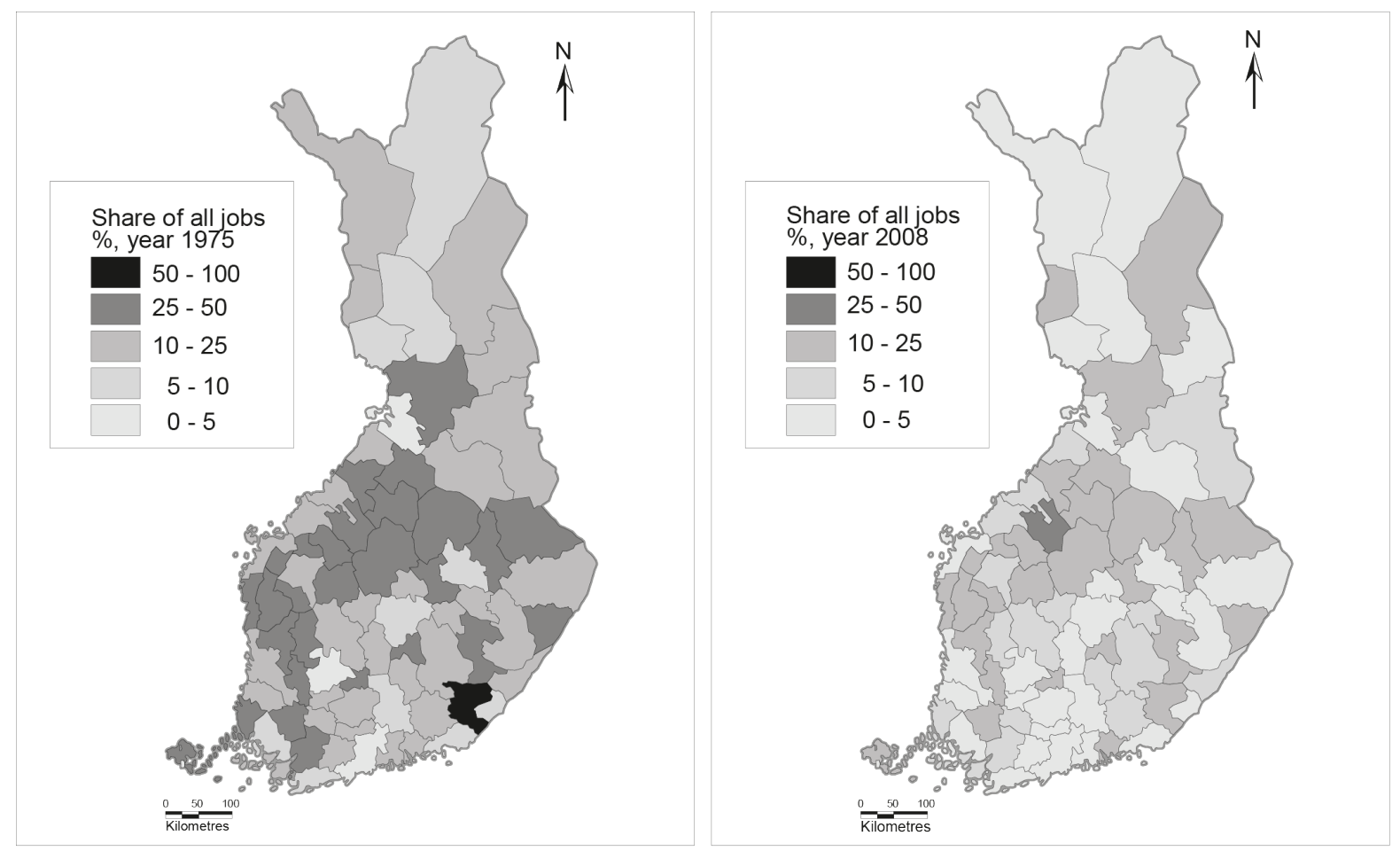

Fig. 2. Share of agricultural jobs in comparison to total employment at the subregional level in 1975 and 2008.
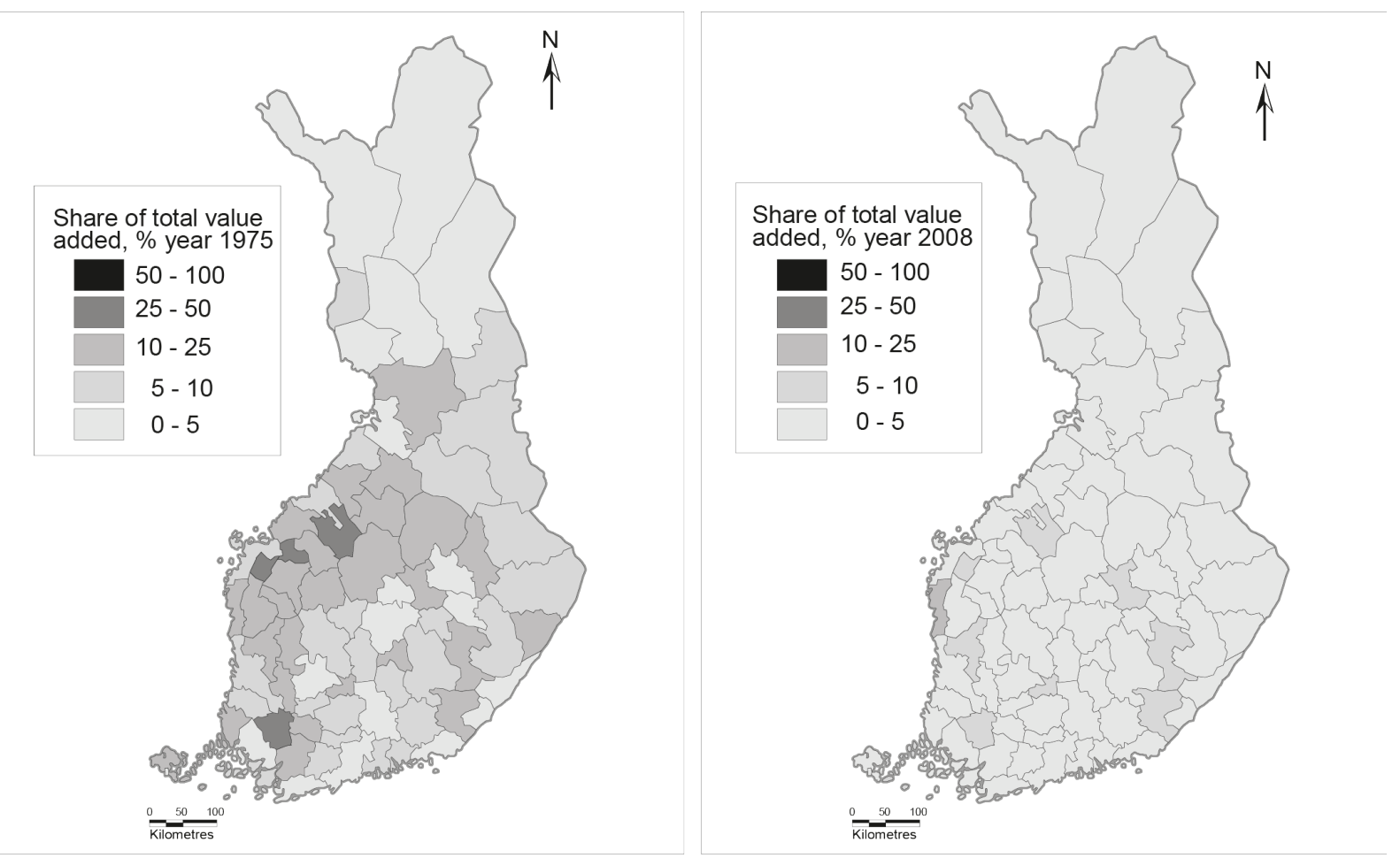

Fig. 3. Share of agriculture in total value added at the subregional level in 1975 and 2008. 


\section{Regional concentration}

Annual shares of agriculture in total employment and total value added are smaller at the country level than the annual mean values of the shares in subregions, although the difference between the annual shares in question has decreased. Hence, there are a lot of subregions where the role of agriculture in terms of employment and value of production is higher than average (Fig. 4).

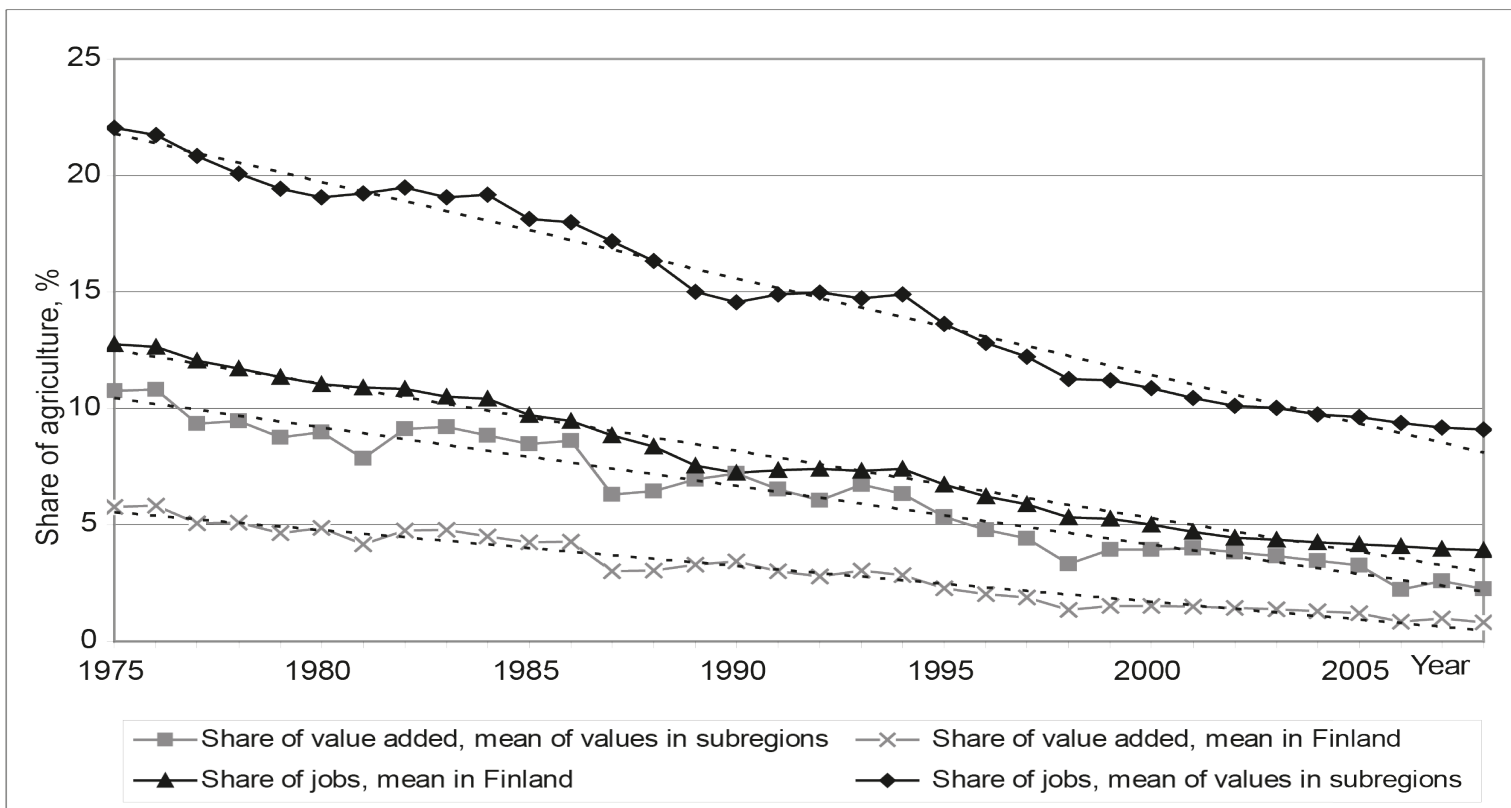

Fig. 4. Shares of agriculture in terms of jobs and value added in the whole country and equivalent mean values of subregions (LAU-1 regions) in 1975-2008.

As described in earlier, the Gini index can be employed for analysing regional concentration or dispersion. The Gini index is at its maximum value 1 when activity is perfectly concentrated. Conversely, the Gini index is at its minimum value 0 when activity is perfectly dispersed. Change in economic structure and regional division of labour produce concentrations of industries. In total, value added is regionally more concentrated than employment, and concentration development of value added has been faster than the equivalent development of employment in 1975-2008 (Fig. 5). Agriculture, in turn, is less concentrated than all the industries as a whole, both in terms of employment and value added. However, the Gini indices of agriculture both in terms of jobs and value added have grown in 1975-2008, i.e. there has been a regional concentration trend in agriculture.

As in the case of all the industries as a whole, the value added of agriculture is regionally more concentrated than agricultural jobs. However, the concentration development in agricultural jobs is faster than that of value added of agriculture while the equivalent relationship between these development trends is opposite in the case of all the industries as a whole. The value of the Gini index of value added in agriculture has on average risen only slightly during 1975-2008. Instead, the structural change of agriculture that has taken place in the light of the strong decrease in the number of agricultural jobs has also meant that regional concentration of agricultural jobs has strengthened. Hence, the difference between the levels of regional concentrations between agricultural jobs and value added in agriculture has decreased. In addition, as the values of the slopes in Figure 5 indicate, regional concentration development in all industries together, both in terms of jobs and value added, has been faster than regional concentration development of agriculture. 


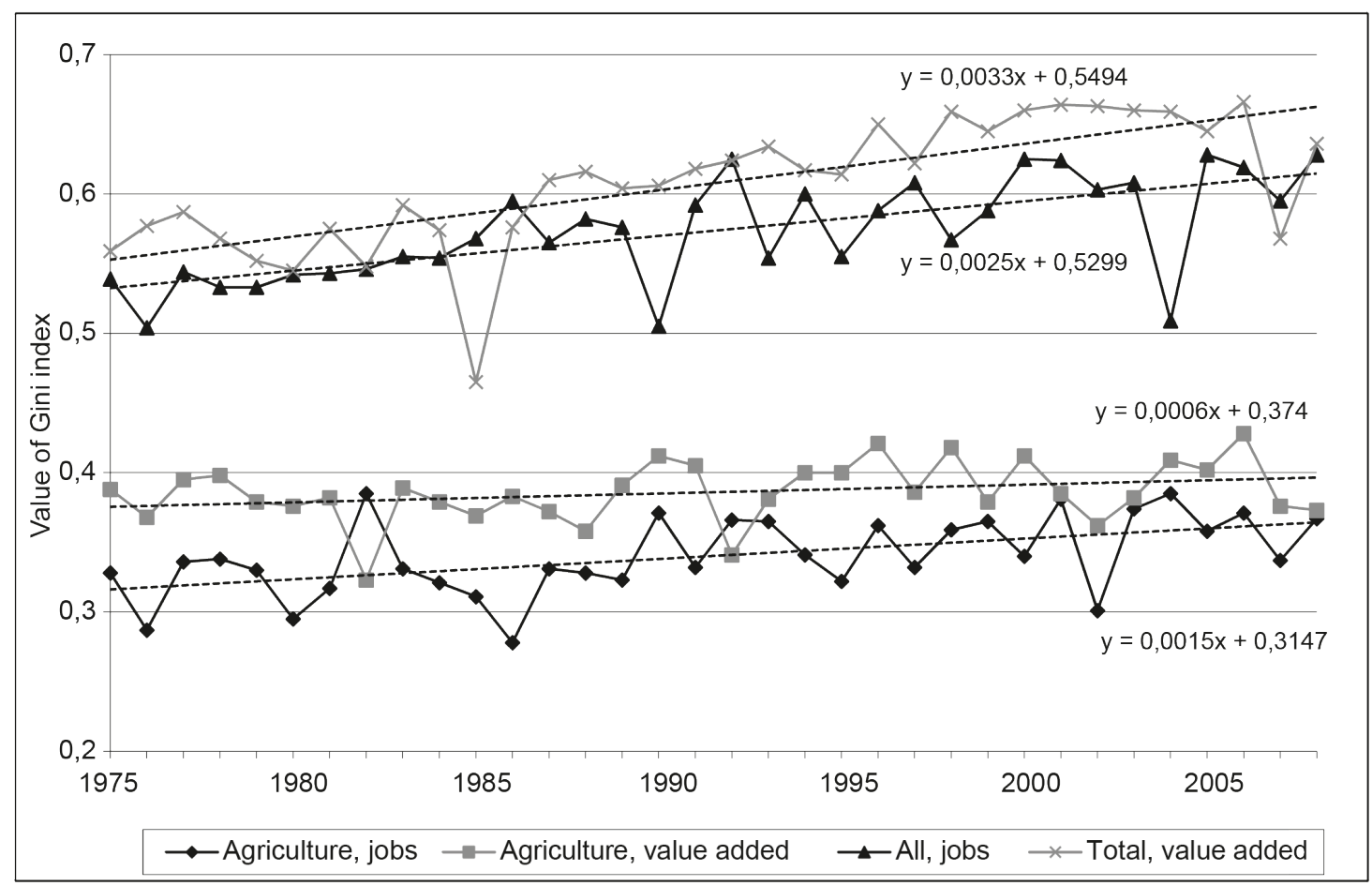

Fig. 5. Regional concentration of jobs and value added in agriculture and in all industries measured by Gini index.

Agricultural jobs in terms of their subregional relative shares in total jobs have concentrated more rapidly than the number of agricultural jobs (Fig. 6). Until 1989, according to trend lines of developments, the agricultural jobs were distributed to the subregions more evenly than the subregional relative shares of agricultural jobs. Since then, the relationship has been opposite.

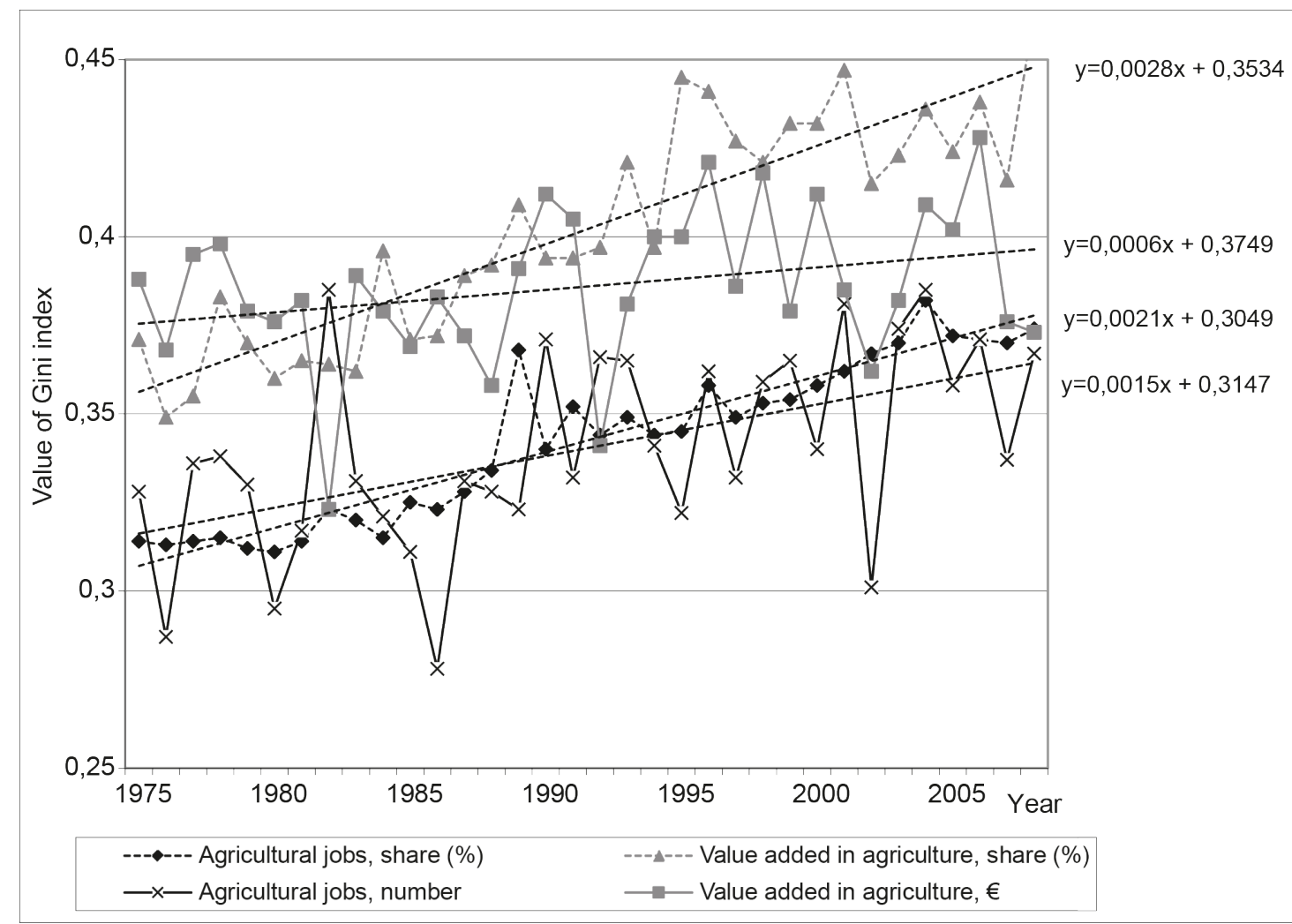

Fig. 6. Gini indices of the agricultural jobs and value added in agriculture and shares of these at the LAU-1 (subregional) level. 
The annual changes and concentration of agricultural jobs and value added at the subregional level have not been constant, i.e., the annual changes have differed from each other. There has been clearly more variation in regional concentration in terms of absolute values in agricultural jobs and value added in agriculture than in terms of their relative subregional shares of total employment and total value added (Figure 6). The Gini index of regional relative shares of value added in agriculture has been higher than the equivalent index of agricultural jobs every year, and the relationship is practically similar in terms of absolute values of value added and employment. This means that value added of agriculture is regionally more concentrated than agricultural jobs. The annual variation of the Gini indices of agricultural jobs (standard deviation 0.028 ) is higher than that of the relative subregional shares of agricultural jobs (standard deviation 0.023). Both the agricultural jobs and the relative shares of these are regionally concentrating but the relative shares of agricultural jobs are concentrating more rapidly than the number of agricultural jobs.

Value added of agriculture in terms of absolute values is concentrating slower than the regional relative shares of value added in agriculture, and since 1984 the Gini index trend of the former has been lower than that of the latter. Furthermore, the annual variation of the Gini indices of value added in absolute values (standard deviation 0.031 ) is higher than that of the relative shares of value added in agriculture (standard deviation 0.023 ).

In summary, agricultural jobs are distributed regionally more evenly than value added of agriculture but concentration development of agricultural jobs is more rapid. Also, the relative shares of agricultural jobs are continuously distributed more evenly than the relative shares of value added in agriculture and the difference is continuously growing.

\section{Discussion}

Based on the analysis in this article, four key conclusions are now presented. First, the structural change of agriculture has been strong all over Finland. Furthermore, as economic functions generally, also agriculture has continuously become regionally concentrated during 1975-2008, although the strongest structural changes in agriculture have already taken place before this. However, during 1975-2008, regional concentration has been stronger in all industries as a whole than agriculture alone. Niemi \& Rikkonen (2010) found that the concentration process of agriculture in Finland has been very similar to the other parts of Europe. Diminishing number of farms and labor force as well as mechanization and intensification of production and growth of regional and farm-specific production have been typical trends in most of the western European countries. In the light of our results it is interesting to notice that the very sparse regional structure of Finnish countryside seems not to have effected very much to this general trend. However, our empirical analysis gives more detailed picture of this development.

The regional concentration trend of agriculture supports the so called New Regional Geography paradigm, i.e., all economic activities are concentrating. In this way, the empirical results of our study conform to a general process of economic development, not only in Finland but also at international level. Bowler (1986), for example, found that the degree of regional changes in agriculture had varied by a product and a region in the then European Community member countries, but similar types of changes had been produced under widely varying national economic conditions. Bowler (ibid.) also found that no simple relations exist between the CAP and the agricultural changes, and that the national and regional advantages in the production costs are difficult to specify (see also Niemi and Rikkonen 2010, 4). van Leeuwen et al. (2010) found in their study on the EU-9 countries that land-intensive, high yielding agricultural products tend to be produced in close to urban areas (in the Finnish case close to densely populated areas in general), and this concentration has increased in the period 1950-2000. Chevassus-Lozza and Daniel (2006) concluded that the more an agricultural sector is open to competition, the more related activity is concentrated in French regions. Their results therefore suggest that the increasing openness of markets should strengthen sub-national concentration process.

Secondly, as a result of the changes in economic structure in Finland, the importance of agriculture in terms of jobs and value added varies notably between the regions. Generally, the relative socioeconomic importance of agriculture has decreased practically all over the country. However, when the regions were compared to each other and looking at the regional relative shares of agricultural jobs and value added in agriculture, the relative importance of agriculture in terms of jobs and value added has increased in many subregions. This tells us that socioeconomic activities other than agriculture may have decreased even faster than agriculture in these regions. 
Thirdly, the development trends of total value added and value added in agriculture seemed to have diverged from each other in Finland since the mid-1980s, as is also the case when comparing total employment and agricultural jobs. All in all, agricultural development trends both in terms of jobs and value added, have been different from total economic development since the mid-1980s. The results tell us that during the last decades, productivity of agriculture has not been as strong as that of all industries together. Furthermore, the role of agriculture as an employer is continuously becoming weaker and the decrease in agricultural jobs is and must be compensated for with other jobs.

Fourthly, compared to other industries and in spite of the regional concentration process, agriculture is still regionally evenly dispersed in Finland. The reasons behind this can be found in historical, societal and political factors. Agriculture is also a so called areal industry; practicing agriculture is often tied to land, large surface area and natural circumstances. The more even regional dispersion of agriculture is also the result of non-economic functions of agriculture (e.g. landscape maintenance).

\section{Acknowledgements}

This study is partly financed by the Rural Policy Committee of Finland. The authors also wish to thank Jaana Ahlstedt for editing the figures and Aaron Bergdahl for his highly professional revision of English language. The study was carried out when Olli Voutilainen was working at MTT Agrifood Research Finland.

\section{References}

Ajo, R. 1947. Liikennealueiden kehittyminen Suomessa. Fennia 69: 3.123 p.

Alalammi, P. 1982. Maatilatalouden edellytykset. In: Suomen Kartasto, vihko 231: Maatilatalous. Helsinki: Maanmittaushallitus ja Suomen maantieteellinen seura. p. 2-3. (in Finnish).

Alestalo, J. 1965. Die anbaugebiete von Ackerplanzen in Finnland. Fennia 92: 4: 1-36. (in German).

Armstrong, H. \& Taylor, J. 2000. Regional economics and policy. $3^{\text {rd }}$ ed. Oxford: Blackwell Publishers. 437 p.

Bowler, I. 1986. Intensification, concentration and specialisation in agriculture: the case of the European Community. Geography 71: 1: 14-24.

Breman, B., Vihinen, H., Tapio-Biström, M.-L. \& Pinto Correia, T. 2010. Disentangling marginalisation processes at the periphery of Europe: a challenge for more diversified regional policies. Public Administration 88: 364-380.

Chevassus-Lozza, E. \& Daniel, K. 2006. Market openness and geographical concentration of agricultural and agro-food activities: the challenges for French regions. Canadian Journal of Regional Science XXIX: 1: 21-42.

Finnish Meteorological Institute a. Seasons in Finland. Cited 30 January 2012. Available on Internet: http://en.ilmatieteenlaitos. $\mathrm{fi} /$ seasons-in-finland.

Finnish Meteorological Institute b. Terminen kasvukausi. Cited 30 January 2012. Available on Internet: http://ilmatieteenlaitos. fi/terminen-kasvukausi.

Fogelberg, P. 1965. Regionale Differenzierung in der finnischen Landwirtschaft. Einige Beispiele im Licht der Landwirtschaftszählung 1959. Fennia 92: 5: 1-50. (in German).

Fujita, M., Krugman, P. \& Venables, A. J. 1999. The spatial economy. Cities, regions and international trade. Cambridge: The MIT Press. 367 p.

Granberg, L. 1989. Valtio maataloustulojen tasaajana ja takaajana. Suomen Tiedeseura 138. Helsinki: Suomen Tiedeseura. 214 p. (in Finnish).

Grigg, D. 1995. An Introduction to Agricultural Geography. $2^{\text {nd }}$ ed. London and New York: Routledge. 217 p.

Huovari, A., Kangasharju, A. \& Alanen, A. 2001. Alueiden kilpailukyky (English abstract: Regional competitiveness). Pellervon taloudellisen tutkimuslaitoksen raportteja 176 / Pellervo Economic Research Institute Reports No. 176. Helsinki: Pellervon taloudellinen tutkimuslaitos. $130 \mathrm{p}$.

Huurre, M. 2003. Maatalouden alku Suomessa. In: Rasila, V., Jutikkala, E. \& Mäkelä-Alitalo A. (eds.). Suomen maatalouden historia I. Perinteisen maatalouden aika: Esihistoriasta 1870-Iuvulle. Helsinki: Suomalaisen kirjallisuuden seura. p. 38-66. (in Finnish).

Häkkilä, M. 1984. Geographical aspects of the development and utilization of arable land area in Finland. Fennia 162: 2: $217-235$.

Junttila, T. 1991. Maatalouden alueellinen työnjako Suomessa. Raportteja ja artikkeleita nro 15. Seinäjoki: Helsingin yliopisto. Maaseudun tutkimus- ja koulutuskeskus. 87 p. (in Finnish).

Jussila, H. 1987. Spatial diffusion of modernization. A study of farm mechanization in Finland at regional and local levels. Research Institute of Northern Finland A; 4. Oulu: University of Oulu. 123 p.

Katajamäki, H. 1988. Alueellisen työnjaon muotoutuminen Suomessa (Abstract: The formation of the spatial division of labour in Finland). Turun yliopiston maantieteen laitoksen julkaisuja 121. Turku: Turun yliopiston maantieteen laitos. 144 p. (in Finnish).

Krugman, P. 1991. Geography and trade. Cambridge: The MIT Press. 142 p.

Krugman, P. 1998. What's new about the New Economic Geography? Oxford Review of Economic Policy 14: 7-17. 
Krugman, P. 2011. The New Economic Geography, Now Middle-aged. Regional Studies 45: 1-7.

Malinen, P., Kytölä, L., Keränen, H. \& Keränen, R. 2006. Suomen maaseututyypit 2006 (English summary: Rural typology of Finland in 2006). Maa- ja metsätalousministeriö 7/2006. Maa- ja metsätalousministeriö. 67 p.

Malinen, P. \& Muilu, T. 2009. Syrjäisen maaseudun kehittäminen - verkkokurssia tukeva opetusmoniste. Redec Kajaani, Working Papers 67. Kajaani: Oulun yliopisto, Kajaanin kehittämiskeskus. 60 p. (in Finnish).

Massey, D. 1984. Spatial divisions of labour: social structures and the geography of production. London: Macmillan. 339 p.

Muilu, T. 1990. Trends in the labour input into agriculture in Northern Finland. Geographica lugoslavica - Bulletin of the Union of the Geographical Societies of Yugoslavia. Ljubljana: VB \& S. p. 201-213.

Myrdal, G. 1957. Economic theory and underdeveloped regions. London: Gerald Duckworth. 168 p.

Niemelä, J. 2004. Hevosista traktoreihin - lannasta väkilannoitteisiin. In: Markkola, P. (ed.). Suomen maatalouden historia III. Suurten muutosten aika. Jälleenrakennuskaudesta EU-Suomeen. Helsinki: Suomalaisen kirjallisuuden seura. p. 187-232. (in Finnish).

Niemi, J. \& Ahlstedt, J. (eds.) 2010. Finnish Agriculture and Rural Industries 2009. MTT Economic Research, Agrifood Research Finland. Publications 110a. Helsinki: MTT Economic Research, Agrifood Research Finland. 96 p.

Niemi, J. \& Ahlstedt, J. (eds.) 2011. Finnish Agriculture and Rural Industries 2008. MTT Economic Research, Agrifood Research Finland. Publications 111a. Helsinki: MTT Economic Research, Agrifood Research Finland. 96 p.

Niemi, J. \& Rikkonen P. (eds.) 2010. Maatalouspoliittisen toimintaympäristön ennakointi. Miten käy kotimaisen elintarvikeketjun? MTT Raportti 7. p. 75-89. (in Finnish).

Niemi, R. \& Häkkilä, M. 1988. Maatalouspolitiikasta ja maatalouden rakenteen alueellisista muutoksista Suomessa ja Ruotsissa 1950-luvulta 1980-luvulle. Oulun yliopisto. Pohjois-Suomen tutkimuslaitos, C 84 . Oulu. 85 p. (in Finnish).

Orrman, E. 2003. Keskiajan maatalous. In: Rasila, V., Jutikkala, E. \& Mäkelä-Alitalo A. (eds.). Suomen maatalouden historia I. Perinteisen maatalouden aika: Esihistoriasta 1870-luvulle. Helsinki: Suomalaisen kirjallisuuden seura. p. 87-114. (in Finnish).

Ottaviano, G.I.P. \& Pinelli, D. 2004. The challenge of globalization for Finland and its regions: The new economic geography perspective. Prime Minister's Office: Publications 24/2004. 84 p.

Peltonen, M. 2004. Torpparikysymys. In: Peltonen, M. (ed.). Suomen maatalouden historia II. Kasvun ja kriisien aika 1870-Iuvulta 1950-luvulle. Helsinki: Suomalaisen kirjallisuuden seura. p. 217-262. (in Finnish).

Pyykkönen, P. 2001. Maatalouden rakennemuutos eri alueilla (English abstract: Regional differences in structural change of Finnish agriculture). Pellervon taloudellisen tutkimuslaitoksen raportteja 180 / Pellervo Economic Research Institute Reports 180. Helsinki: Pellervo economic research institute. $61 \mathrm{p}$

Rantatupa, H. 2004. 1930-luvun pulavuodet ja maatalouskiinteistöjen pakkohuutokaupat. In: Peltonen, M. (ed.). Suomen maatalouden historia II. Kasvun ja kriisien aika 1870-luvulta 1950-luvulle. Helsinki: Suomalaisen kirjallisuuden seura. p. 419-442. (in Finnish).

Roiko-Jokela, H. 2004. Asutustoiminnalla sodasta arkeen. In: Markkola, P. (ed.). Suomen maatalouden historia III. Suurten muutosten aika. Jälleenrakennuskaudesta EU-Suomeen. Helsinki: Suomalaisen kirjallisuuden seura. p. 27-53. (in Finnish).

Rosenqvist, O. 1997. Maatalouden alueellinen erikoistuminen Suomessa (English abstract: Regional specialisation of agriculture in Finland). Vaasan yliopiston julkaisuja, Tutkimuksia 219/Proceedings of the University of Vaasa, Research Papers 219. Vaasa: Vaasan yliopisto. $211 \mathrm{p}$.

Shucksmith, M., Thomson, K.J. \& Roberts, D. (eds.) 2005. CAP and the regions: the territorial impact of the Common Agricultural Policy. Wallingford: CABI Publishing. 232 p.

Smeds, H. 1963a. Förändringar i Finlands jordbruksgeografi under efterkrigstiden. Nordenskiöld-samfundets tidsskrift 23: 3-31. (in Swedish).

Smeds, H. 1963b. Några synpunkter på världens livsmedelsförsörjning. Nordisk lantbruksekonomisk tidskrift 13: 3: 108-118. (in Swedish).

Soininen, A. 1974. Vanha maataloutemme : maatalous ja maatalousväestö Suomessa perinnäisen maatalouden loppukaudella 1720-luvulta 1870-luvulle. Historiallisia tutkimuksia 96. Helsinki: Suomen historiallinen seura. 459 p. (in Finnish).

Statistics Finland. Suomen virallinen tilasto (SVT). Aluetilinpito [e-publication]. Helsinki: Tilastokeskus. Cited 10 January 2012. Available on the Internet: http://www.stat.fi/til/altp/index.html.

Talman, P. 1980. Karjatalouden alueellinen rakenne Suomen maatilataloudessa 1970-luvulla. Nordia tiedonantoja 7. Oulu: Pohjois-Suomen maantieteellinen seura. 51 p. (in Finnish).

Talman, P. 1981. Features of the structural development of animal husbandry on Finland in the period 1950-1974. In: Koutaniemi, L. (ed.) 1981. Papers presented to professor Uuno Varjo, head of the Department of Geography, University of Oulu, on the occasion of his sixtieth birthday, 7th march 1981. Oulun yliopiston maantieteen laitoksen julkaisuja, nro 73. p. 79-90.

Tohmo, T. 2007. Regional Economic Structures in Finland. Analysis of Location and Regional Economic Impact. Jyväskylä Studies in Business and Economics 57. Jyväskylä: University of Jyväskylä. 57 p.

Tohmo, T. \& Littunen, H. 2002. Maakuntien vahvuusalat ja toimialarakenteen erikoistuminen. Kansantaloudellinen aikakauskirja 4/2002: 409-416. (in Finnish).

Tykkyläinen, M. \& Kavilo, S. 1991. Maaseudun asuttaminen ja talouden rakennemuutos Suomessa (English abstract: Rural settlement and economic restructuring in Finland). Research reports in human geography and planning, University of Joensuu, Faculty of Social Sciences, No. 2. Joensuu: University of Joensuu.114 p.

UNESCO. IDAMS Statistical Software. UNESCO and Information processing tools. Cited 9 January 2012. Available on the Internet: http://portal.unesco.org/ci/en/ev.php-URL_ID=2070\&URL_DO=DO_TOPIC\&URL_SECTION=201.html. 
van Leeuwen, E.S., Strijker, D. \& Terluin, I.J. 2010. Regional concentration and specialisation in agricultural activities in EU-9 regions (1950-2000). European Spatial Research and Policy 17: 1: 23-39.

Varjo, U. 1956. Landschaft und Landwirtschaft im südwestlichen Finnland. Turun yliopiston julkaisuja, Sarja A, Physico-mathematica, physica, 21. Turku: Turun yliopisto. 168 p. (in German).

Varjo, U. 1977a. Finnish farming: typology and economics. Research Institute of Geography, Hugarian Academy of Sciences. Geography of world agriculture 6. Akadémiai Kiadó, Budapest. 146 p.

Varjo, U. 1977b. Suomen maatilamaantiede. Oulun Yliopisto, Maantieteen Laitos. 224 s. (in Finnish).

Varjo, U. 1980. On the location of agriculture in Finland. Nordia 1980 Vol. 14 No. 1: 1-15.

Venables, A. 1996. Equilibrium locations of vertically linked industries. International economic review 37: 341-359.

Voutilainen, O. 2012. Relationship between Agricultural and Rural Development within the Context of the European Union's Common Agricultural Policy: the Case of Finland. (Doctoral Dissertation) MTT Science 19. Jokioinen: MTT Agrifood Research Finland.135 p.

Yrjölä, T. 2010. Elintarviketuotannon globaali rakennekehitys, alueellinen sijoittuminen ja politiikat. In: Niemi, J. \& Rikkonen P. (eds.). Maatalouspoliittisen toimintaympäristön ennakointi. Miten käy kotimaisen elintarvikeketjun? MTT Raportti 7. Jokioinen: MTT Agrifood Research Finland. p. 75-89. (in Finnish).

Östman, A.-C. 2004. Mekanisoinnin ensimmäinen aalto. In: Peltonen, M. (ed). Suomen maatalouden historia II. Kasvun ja kriisien aika 1870-luvulta 1950-luvulle. Helsinki: Suomalaisen kirjallisuuden seura. p. 19-134. (in Finnish). 